ISSN 1112-9867

\title{
THE ANTIFEEDANT ACTIVITY OF ESSENTIAL OIL FROM CYMBOPOGON CITRATUS AND PIPER BITLE FOR CONTROLLING GOLDEN APPLE SNAIL, POMACEA CANALICULATA
}

\author{
R. Ibrahim ${ }^{1}$, Z. A. Haiyee ${ }^{2}$ and S. N. H. M. Latip ${ }^{1, *}$ \\ ${ }^{1}$ Faculty of Plantation and Agrotechnology, UniversitiTeknologi MARA, 40450 Shah Alam, \\ Selangor, Malaysia \\ ${ }^{2}$ Faculty of Applied Sciences, UniversitiTeknologi MARA, 40450 Shah Alam, Selangor, \\ Malaysia
}

Published online: 10 November 2017

\begin{abstract}
Golden apple snail, Pomaceacanaliculata (GAS) inflicted damage in major paddy granary areas in Malaysia with estimated infected area more than 17,000 ha. Farmers use synthetic pesticide to control GAS infestation because its rapid effect. However, excessive application had led to environmental pollution and hazard to applicators. There were many research on biopesticide had been done in order to reduce the dependency on synthetic pesticide. This research conducted to identify the active compounds of essential oil from lemongrass (Cymbopogoncitratus)and betel(Piper bitle) by GCMS. The bioassay and antifeedant activity test conducted to evaluate the effectiveness of this essential oil in controlling GAS population. The result from antifeedant activity test foressential oil of lemongrass showed high antifeedent activity, compared with essential oil of betel for controlling GAS.
\end{abstract}

Keywords: golden apple snail; piper bitle; Cymbopogoncitratus; essential oil; antifeedant.

\footnotetext{
Author Correspondence, e-mail: noorhajar@salam.uitm.edu.my doi: http://dx.doi.org/10.4314/jfas.v9i6s.4
} 


\section{INTRODUCTION}

Rice mainly produced in Asian region over $60 \%$ of crop grown. High demand of rice is higher compared with other staple food for majority of Asian people [1]. In rice producing country, Pomaceacanaliculata, golden apple snail (GAS) caused great losses when attacking young leaves and stem of paddy [2]. GAS has been introduced into different countries of Southeast Asia and North America from place of origin from South American habitats for aquarium pet or food trade before becomes major pests of paddy [3]. Majority of Asian farmers commonly usedmolluscicides such as metaldehyde and niclosamidedue to its rapid prompt effect in terms of time [4]. However, the constant application of heavy pesticides caused various problems such as environmental pollution, resurgence and pesticides resistance, increase costs of application and effect to non-target organisms [5]. Due to the awareness of toxic hazards from synthetic molluscicides, botanical pesticides were the best alternative for reducing GAS damage in paddy fields [6].

There were many plants having molluscicidal properties against GAS either through plant extracts or traditionally practiced [1]. The secondary metabolites presence in plants such as phenols, flavonoids, terpenoids, quinines, tannins, alkaloids, saponins, coumarins and sterols was involved in plant defences, showing different reaction towards pest species [7].

The essential oil which consists of terpenoids responsible for the aroma and flavor associated with herbs, spices and perfumes [8]. The report from previous research on essential oil showed its function as antimicrobial, antifungal, molluscicidal, nematicidal, antioxidant andantiflatoxigenic activities [9]. Terpenoids such as citral, geraniol, limonene, pinene, citronellol, citronellal and linalool was the importance compounds which can act as insect repellent [7]. The plants which had been evaluated for mollucicidal activity such as Blumeabalsamifera, Jatrophamenispermum,Capsicumfrutescens, Nicotianatabacum(tobacco),Croton tiglium(tubing kamaisa),Derris philippinensis(tubli roots),Tinosporarumphii, Menispernum calculus and MitisCitriandAzadirachtaindica [1].

Previous studies has identified lemongrass showed pharmacological activities which act as anti-amoebic, antibacterial, antidiarrheal, antifilarial, antifungal and anti-inflammatory properties. Terpenes, alcohols, ketones, aldehyde and esters were main chemical compounds identified in Cymbopogoncitratus (lemongrass). Essential oillemongrasswas effective against 
keratinophilic fungi, ringworm fungi and food storage fungi. It is also good as herbicide and insecticide due to naturally occurring antimicrobial effects [10]. The contact toxicity bioassay conducted for essential oil of lemongrass exhibited 100\% mortality and zero eggs laid forCallosobruchusmaculatus (F.) in stored cowpea at concentration of $0.15 \mathrm{~g} / 1$ [11].

Phytochemical screening of the methanol extract of Piper betle L. (betel) leaves revealed that the leaf extract contains alkaloids, terpenes, anthraquinones, flavonoids, tannins, saponins and steroids. It was identified as active antiprotozal and antimalarial agents in many pharmacological studies [12]. The fresh betel had shown antimicrobial, ringworm, antifungal, antiseptic and antihelminthic effects [13]. Essential oil of betel giving better protection from mosquitoes Anopheles stephensi and Culexfatigans biting compared to known mosquito repellent citronella oil. For application at the rate of $20 \mu 1 / \mathrm{cm}^{2}$, essentiall oil of betel giving more than 4 hours protection against Anopheles stephensi and Culexfatigans when citronella oil provided only 2.2 and 2.6 hours protection respectively. Essential oil of betelhad shown more fumigant action than citronella oil against Anopheles stephensi and Culexfatigans where the $\mathrm{LC}_{50}$ value was 24.81 and $20.51 \mu \mathrm{l} /$ liter air respectively, whereas $\mathrm{LC}_{50}$ of citronella oil was 32.71 and $31.97 \mu \mathrm{l} /$ liter air respectively. Both essential oil of betel and citronella showed $100 \%$ repellency against Anopheles stephensi and Culexfatigans at rate $10 \mu \mathrm{l} / \mathrm{cm}^{2}$. However, at low concentration essential oil ofbetel exhibited more repellency against both the mosquito sp. than citronella oil [14].

The objectives of this study was to identify and quantify the compounds from essential oil extract and evaluate the antifeedants activity of essential oil extract from lemongrass and betel for controlling GAS.

\section{EXPERIMENTAL}

\subsection{Golden Apple Snail}

An adult of GAS were collected from paddy field at TanjongKarang, Selangor. The range size of golden apple snail was 20-35 mm height.

\subsection{Essential Oil Extraction}

Study was carried out with extracted essential oil from leaves of lemongrass and betel. The hydrodistillation method was used to extract essential oilbased on methodology by [15] with 
some modification. The liquid-liquid extraction used to separate oil from water distillate and then was extracted by rotary evaporator. The percentage of essential oil produced for fresh lemongrass leaves was $0.5 \%$, while for betel essential oil was $1.9 \%$ from fresh weight basis.

\subsection{Quantification of Active Compounds}

The essential oil of lemongrass and betel were analysed by using Gas Chromatography Mass Spectrometry (GCMS) method by [23]with some modification. The type of column used was HP-5MS capillary column (Agilent 19091S-433 of $30 \mathrm{~m}$ long, $0.25 \mathrm{~mm}$ inner diameter (id) and $0.25 \mathrm{~lm}$ film thicknesses). GCMS instrument used was equipped with mass selective detector with electron impact mode $(70 \mathrm{eV})$. The temperature of column were set at $60^{\circ} \mathrm{C}$ to $325^{\circ} \mathrm{C}$ with holding time of $10^{\circ} \mathrm{C} / \mathrm{min}$. Helium gas used as carrier gas with flow rate of 1.0 $\mathrm{ml} / \mathrm{min}$ in splitless mode. $1 \mu \mathrm{l}$ solution $(0.1 \%$ essential oil in hexane) injected into GC by auto-sampler. The data from GC analysis compared with NIST library for identification of active compounds [15].

\subsection{Antifeedant Activity Test}

The test was conducted by following method of [16-17] with some modification. Five treatments concentration was prepared which are $0.02 \mathrm{~g} / \mathrm{ml}, 0.04 \mathrm{~g} / \mathrm{ml}, 0.06 \mathrm{~g} / \mathrm{ml}, 0.08 \mathrm{~g} / \mathrm{ml}$ and $0.10 \mathrm{~g} / \mathrm{ml}$ with 3 replicates each. The distilled water used as a control in this experiment. For each treatment, $10 \mathrm{ml}$ of solution sprayed onto paddy. Data of weight GAS and paddy before test and after 7 days of treatment were recorded. Paddy weight loss was calculated using this formula:

Weight loss $(\% \mathrm{WL})=(\mathrm{IW}-\mathrm{FW}) \mathrm{X} 100 / \mathrm{IW}$

whereIW: Initial weight and FW: Final weight.

The result for GAS mortality of the control corrected using Abbott's formula and expressed in percentages [18-19]. Significant of mean difference between treatment and control was analysed.

\section{RESULTS AND DISCUSSION}

\subsection{Quantification of Active Compounds from Essential oils}

From the GCMS analysis result such in Table 1, major compound from essential oil of lemongrass is citral where $\alpha$ - citral with total percentage area of $9.3 \%$ and $\beta$-citral with $7.4 \%$ 
followed by minor compound of isogeranial $1.9 \%$ and geraniol $1.0 \%$ total area. Meanwhile, major compound from betel essential oil was eugenol which is $15.6 \%$ total area followed by chavicol $4.6 \%$, chavicolaceatate $4.7 \%$ and other minor compound which are $\gamma$-Muurolene, Germacrene D,Isogermacrene, Caryophyllene, Humulene, $\alpha$-Cadinol and Trans-Isoeugenol.

The data of percentage area used to calculate each compound concentration by compared with external standard. For essential oil oflemongrass, concentration of $\alpha$-citral calculated was 38.4 $\mathrm{g} / 100 \mathrm{ml}$ and $\beta$-citral $40.9 \mathrm{~g} / 100 \mathrm{ml}$. Meanwhile, for essential oil of betel, eugenol concentration calculated was $42.4 \mathrm{~g} / 100 \mathrm{ml}$.

\subsection{Antifeedant Activity}

Based on result shown on Fig. 1, GAS weight loss was oppositely proportional to paddy weight loss. Weight of paddy was decreasing with the increasing of essential oil treatment concentration from essential oil of lemongrass treatment. Meanwhile, for betel treatment, paddy weight loss was decreasing from T1 $(0.02 \mathrm{~g} / \mathrm{ml})$ to T3 $(0.06 \mathrm{~g} / \mathrm{ml})$ and slightly increase after T4 $(0.08 \mathrm{~g} / \mathrm{ml})$ treatment concentration. Based on Fig. 1, distilled water control $(\mathrm{CW})$ give the highest paddy weight loss $(31.9 \%)$. Withinthe essential oil of betel treatment,T1 $(0.02 \mathrm{~g} / \mathrm{ml})$ and T2 $(0.04 \mathrm{~g} / \mathrm{ml})$ concentrationgiving higest paddy weight loss $(31.0 \%$ and $28.3 \%)$.Otherwise, for the same treatment, it showed the lowest weight loss of GAS (8.2 and 6.8\%). Meanwhile, T3 $(0.06 \mathrm{~g} / \mathrm{ml})$ and T4 $(0.08 \mathrm{~g} / \mathrm{ml})$ showed the lowest paddy weight loss $(10.2 \%$ and $11.1 \%)$ respectively. The T4 $(0.08 \mathrm{~g} / \mathrm{ml})$ resulted in total GAS mortality andlower slightly atT5 $(0.1 \mathrm{~g} / \mathrm{ml})$ treatment which is $88.6 \%$.Meanwhile, for essential oil of lemongrass treatment T5 $(0.1 \mathrm{~g} / \mathrm{ml})$ showed the lowest paddy weight loss $(7.7 \%)$ while giving the higest weight loss of GAS (787.3\%). This finding revealed the paddy weight loss show a relationship with total weight loss of GAS for bothessential oil of lemongrass and betel treatment. 
Table 1. Percentage of active compounds from essential oil extracted from hydrodistillation

\begin{tabular}{ccc}
\hline Essential Oil & Active Compounds & Area (\%) \\
\hline Lemongrass & $\beta$-citral & 7.4 \\
& $\alpha$ - citral & 9.3 \\
Geraniol & 1 \\
Betel & Isogeranial & 1.9 \\
& Chavicol & 4.6 \\
& Chavicol acetate & 4.7 \\
& Eugenol & 15.6 \\
& Trans-Isoeugenol & 0.2 \\
& Methyleugenol & 0.3 \\
& $90 \gamma$-Muurolene & 1.1 \\
& Germacrene D & 0.9 \\
& Isogermacrene & 0.2 \\
& Caryophyllene & 0.8 \\
& Humulene & 0.3 \\
$\alpha$-Cadinol & 0.2 \\
\hline
\end{tabular}



Fig.1. Weight loss of paddy with different treatment compared with control 


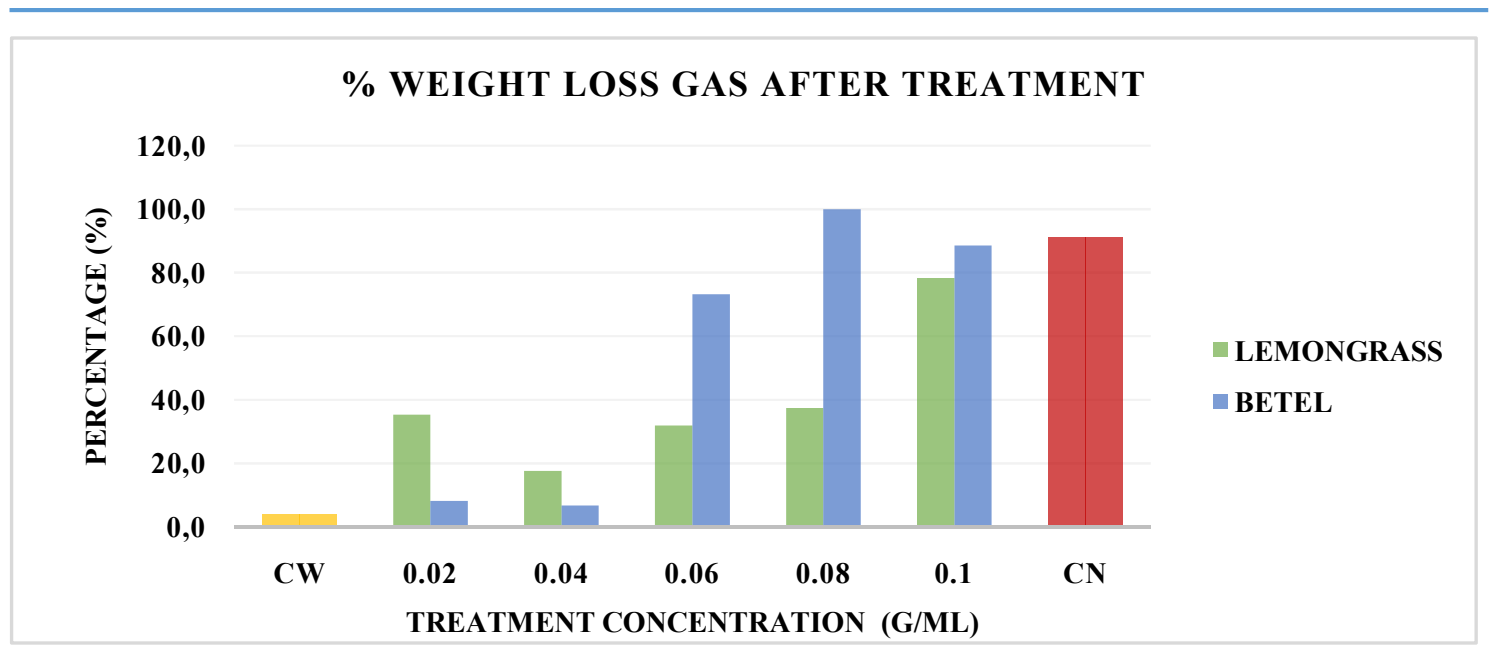

Fig.2. Weight loss of GAS with different treatment compared with control

Result analysis of variance (ANOVA) in Table 2 showed that there was significant increasing $(\mathrm{p}<0.05)$ on GAS mortality as the time of treatment increase for both plants. Mortality of GAS was increase gradually from 24 hours until 96 hours foressential oil of betel and lemongrass treatment. Result from both treatments for tested plant essential oil showed the concentration of essential oil treatment and the exposure time was dependent as there was a significant correlation between the mortality rate of GAS with exposure time and concentrations. However, essential oil of betel treatment give higher mean mortality of GAS compared with essential oil of lemongrass treatment with increase of exposure time compared with essential oil of lemongrass treatment. The highest mean mortality given by essential oil of betel treatment was after 96 hours exposure time, which is $50.0 \mathrm{a} \pm 42.26 \%$ compared with essential oil of lemongrass $(29.3 \mathrm{~b} \pm 24.92 \%)$. The lowest mean mortality was given by essential oil of lemongrass treatment after 24 hours exposure time which is $10.0 \mathrm{a} \pm 11.95 \%$. These results show thatessential oil of betel treatment exhibit very strong activity against GAS compared with essential oil of lemongrasswithin 4 days exposure.

From GCMS analysis result, the highest active compound in essential oil of betel was eugenol which $15.6 \%$. Previous research done by [20]indicate thateugenol can mimicking octopamine in insect which acting as neurotransmitter, neurohormone and circulating hormone, interrupt with its function will cause the total breakdown of nervous system in insect. Eugenol caused the cellular changes in insect by disturbing the octopamine function. The benzene derivatives, eugenol, isoeugenol, methyl eugenol, safrole and isosafrole were more toxic and repellent to 
American cockroach (Periplanetaamaricana) compared with derivatives of terpenes such as cineole, limonene, $\alpha$-pinene and $\rho$-cymene [8].

The highest citral compound from essential oil of lemongrass from GCMS analysis can be factor for antifeedants activity of lemongrass against GAS as mentioned by [21], toxic terpenes act as antifeedants to protect certain plants from consumed by animals. The study conducted by [22], the essential oil treatment might be the reasons of symptoms which stipulate neurotoxic activity such as seizures, hyperactivity and tremors then knock down.

Table 2. Mean (( \pm SEM) of percentage mortality of GAS versus time and plant extracts

\begin{tabular}{ccccc}
\hline $\begin{array}{c}\text { Treatment } \\
\text { Time }\end{array}$ & $\mathbf{2 4} \mathbf{~ h r}$ & $\mathbf{4 8} \mathbf{~ h r}$ & $\mathbf{7 2} \mathbf{~ h r}$ & $\mathbf{9 6} \mathbf{~ h r}$ \\
\hline Lemongrass & $10.0 \mathrm{a} \pm 11.95$ & $21.3 \mathrm{~b} \pm 19.59$ & $26.7 \mathrm{~b} \pm 21.27$ & $29.3 \mathrm{~b} \pm 24.92$ \\
Betel & $12.7 \mathrm{a} \pm 18.31$ & $35.3 \mathrm{a} \pm 33.99$ & $47.3 \mathrm{a} \pm 40.61$ & $50.0 \mathrm{a} \pm 42.26$
\end{tabular}

Means within the same column followed by different letters are significantly different $(\mathrm{P}<0.05)$, LSD t-test

\section{CONCLUSION}

Essential oil of lemongrass at concentration giving the highest antifeedant activity compared with other treatment after 7 days of application. However, essential oil of betel treatment resultsintotalGAS mortality after 7 days treatment application compared with essential oil of lemongrass treatment which show $87 \%$ GAS mortality at highest treatment concentration.Essential oil of lemongrass shown antifeedant activity towards GAS compared with essential oil of betel.It was recommended for both essential oil to be studied further in future and recommended for farmers, since it issafer to environment.

\section{ACKNOWLEDGEMENTS}

We would like to thank all the members from Biopesticide Research Team under supervision of Dr. Siti Noor HajjarMdLatip for supporting and helpful during conducting this study. We wish to thank laboratory technical department from Faculty Plantation and Agriculture, UiTM Shah Alam, UiTMJengka and UiTMPuncakAlam for their cooperation and technical assistance during this study. 


\section{REFERENCES}

[1] Keni M F, Latip S N H M. Azadirachtaindica seed as potential biopesticides for controlling Golden Apple Snail, Pomaceacanaliculata in rice cultivation. In IEEE Business Engineering and Industrial Applications Colloquium, 2013, pp. 251-256

[2] Salleh M N H, Arbain D, Daud M M Z, Pilus N, Nawi R. Distribution and management of Pomaceacanaliculata in the Northen region of Malaysia: Mini review. In 3rd International Conference Biotechnology and Food Science, 2012, pp. 129-134

[3] Arfan A G, Muhamad R, OmarD, Azwady N A A, Manjeri G.Distribution of two pomaceaspp. in rice fields of Peninsular Malaysia. Annual Research and Review in Biology, $2014,4(24): 4123-4136$

[4] Kijprayoon S, Tolieng V, Petsom A, Chaicharoenpong C. Molluscicidalactivity of camellia oleifera seed meal. Science Asia, 2014, 40:393-399

[5] Gill H K, Garg H. Pesticide: Environmental impacts and management strategies. In M. L. Larramendy, \& S. Soloneski (Eds.), Pesticides-Toxic aspect. Rijeka: InTech, 2014, pp. 187-230

[6] Latip $\mathrm{S} \quad \mathrm{N} \quad \mathrm{H}$ M,Abrahim $\mathrm{M} \quad \mathrm{N} \quad \mathrm{F}$, Othman A $\mathrm{S}$ N. Ipomoea aquaticaand pelthoporumpterocarpum extracts as biopesticide for controlling golden apple snail, pomaceacanaliculata.International Journal of Agriculture, Forestry and Plantation, 2015, $1: 13-15$

[7] Raja N. Botanicals: Sources for eco-friendly biopesticides. Journal of Biofertilizers and Biopesticides, 2014, 5:1

[8] Tabassum N, Vidyasagar G M.Antifungal investigations on plant essential oils: A review.International Journal of Pharmacy and Pharmaceutical Sciences, 2013, 5(Suppl 2):19-28

[9] Pugazhvendran S R, Ross R P, Elumalai K. Insecticidal and repellant activities of plants oil against stored grain pest, triboliumcastaneum (herbst) (coleoptera:tenebrioidae). Asian Pacific Journal of Tropical Disease, 2012, 2:412-415 
[10] Shah G, Shri R, Panchal V, Sharma N, Singh B, Mann A S. Scientific basis for the therapeutic use of cymbopogon citrates, stapf (lemongrass). Journal of Advanced Pharmaceutical Technology and Research, 2011, 2(1):3-8

[11] Paranagama P A, Adhikari A A C K, Abeywickrama K P, K A NP Bandara. Toxicity and repellant activity of cymbopogoncitratus (d.c) stapf. andmurrayakoenigiisprang against callosobruchusmaculatus(f.) (coleoptera; bruchidae). Tropical Agricultural Research and Extension, 2002, 5(1\&2):1

[12] Abdullah H A, Zurainee M N, Hesham M A, Adel A A, Rohela M. Antimalarial activity of methanolic leaf extract of piper betleL.Molecules,2011,16(1):107-118

[13] Pradhan D, Biswasroy P, Suri K A. Variation in the percentage content of hydroxychavicol in different extracts of piper betleL. by altering the extraction parameters. International Journal of Advanced Scientific and Technical Research, 2014, 2(4):517-530

[14] Pal M, Chandrashekar K. Mosquito repellent activity of piper bitle Linn. International Journal of Pharmacy and Life Sciences, 2010, 1(6):313-315

[15] Zaibunnisa A H, Norashikin S, Mamot S, Osman H. An experimental design approach for the extraction of volatile compounds from turmeric leaves (curcuma domestica) using pressured liquid extraction (PLE). LWT-Food Science and Technology, 2009, 42(1):233-238

[16]Adenusi A A, Odaibo A B. Laboratory assessment of molluscicidalantivity of crude aques and ethanolicextacts of dalbergiasisso plant parts against biophalariapfeifferi. Journal of Travel Medicine and Infectious Disease, 2008, 6(4):219-227

[17] Pinto Z T, Sánchez F F, dos Santos A R, Fernandez A A C, Ferreira J L P, Escalona-Arranz J C, Queiroz M M C. Chemical composition and insecticidal activity of cymbopogoncitratus essential oil from Cuba and Brazil against housefly. Brazilian Journal of Veterinary Parasitology, 2015, 24(1):36-44

[18] Abbott W. A method of computing the effectiveness an insecticide. Journal Economic Entomology, 1925, 18(2):265-267

[19] Latip S N H M, Nawi M F W, Shari E S. Potency of manihotesculentacrantz and artocarpus integer extracts as botanical pesticides for controlling, golden apple snail, Pomaceacanaliculata, 2015

[20] Tripathi A K, Upadhyay S, Bhuiyan M, Bhattacharya P R. A review on prospect of 
essential oils as biopesticide in insect-pest management. Journal of Pharmacognosy and Phytotheraphy, 2009, 1(5):52-63

[21] Onyeike E N, Ikewuchi J C, Ikewuchi C C, Uwakwe A A. Quantitative high performance liquid chromatographic analysis of simple terpenes, carotenoids, phytosterols and flavonoids in the leaves of acalyphawilkesianamuell arg. Pacific Journal of Science and Technology, 2010, 11(2):480-487

[22] Kostyukovsky M. A., Rafaeli, C., Gileadi, N., Demchenko, and Shaaya, E. Activation of octopaminergic receptors by essential oil constituent isolated from aromatic plants: Possible mode of action against insect pest. Pest Management Science, 2002, 58(11):1101-1106

\section{How to cite this article:}

Ibrahim R, Haiyee Z A, Latip S N H M. The antifeedant activity of essential oil from cymbopogon citratus and piper bitle for controlling golden apple snail, pomacea canaliculata. J. Fundam. Appl. Sci., 2017, 9(6S), 39-49. 